\title{
Biome-specific effects of nitrogen and phosphorus on the photosynthetic characteristics of trees at a forest-savanna boundary in Cameroon
}

\author{
Tomas Ferreira Domingues · F. Yoko Ishida • Ted R. Feldpausch • John Grace • \\ Patrick Meir · Gustavo Saiz • Olivier Sene • Franziska Schrodt • Bonaventure Sonké • \\ Herman Taedoumg $\cdot$ Elmar M. Veenendaal $\cdot$ Simon Lewis $\cdot$ Jon Lloyd
}

Received: 25 May 2014 / Accepted: 28 January 2015 / Published online: 10 March 2015

(c) The Author(s) 2015. This article is published with open access at Springerlink.com

\begin{abstract}
Photosynthesis/nutrient relationships of proximally growing forest and savanna trees were determined in an ecotonal region of Cameroon (Africa). Although area-based foliar $\mathrm{N}$ concentrations were typically lower for savanna trees, there was no difference in photosynthetic rates between the two vegetation formation types. Opposite to N, area-based P concentrations were- on average-slightly lower for forest trees; a dependency of photosynthetic characteristics on foliar $\mathrm{P}$ was only evident for savanna trees. Thus savanna trees use $\mathrm{N}$ more efficiently than their forest counterparts, but only in the presence of
\end{abstract}

Communicated by David Tissue.

Electronic supplementary material The online version of this article (doi:10.1007/s00442-015-3250-5) contains supplementary material, which is available to authorized users.

T. Ferreira Domingues $\cdot$ J. Grace $\cdot$ P. Meir

School of GeoSciences, University of Edinburgh, Edinburgh, UK

T. Ferreira Domingues

Faculdade de Filosofia Ciências e Letras de Ribeirão Preto,

Universidade de São Paulo, São Paulo, Brazil

F. Y. Ishida

Instituto Nacional de Pesquisas da Amazonia, Manaus, Brazil

F. Y. Ishida $\cdot$ J. Lloyd $(\square)$

Centre for Tropical Environmental and Sustainability Sciences (TESS) and School of Marine and Tropical Biology, James Cook University, Cairns, QLD, Australia

e-mail: jonathan.lloyd@imperial.ac.uk

T. R. Feldpausch $\cdot$ F. Schrodt $\cdot$ S. Lewis

School of Geography, University of Leeds, Leeds, UK

T. R. Feldpausch

College of Life and Environmental Sciences, University

of Exeter, Exeter, UK relatively high foliar P. Along with some other recent studies, these results suggest that both $\mathrm{N}$ and $\mathrm{P}$ are important modulators of woody tropical plant photosynthetic capacities, influencing photosynthetic metabolism in different ways that are also biome specific. Attempts to find simple unifying equations to describe woody tropical vegetation photosynthesis-nutrient relationships are likely to meet with failure, with ecophysiological distinctions between forest and savanna requiring acknowledgement.

Keywords Tropical rain forest $\cdot$ Nutrient $\cdot$ Global change $\cdot$ Terrestrial productivity $\cdot$ Photosynthesis

\footnotetext{
G. Saiz

Centre for Tropical Environmental and Sustainability Sciences (TESS) and School of Earth and Environmental Science, James Cook University, Cairns, QLD, Australia

G. Saiz

Karlsruhe Institute of Technology, Institute of Meteorology and Climate Research, Garmisch-Partenkirchen, Germany

O. Sene $\cdot$ B. Sonké $\cdot$ H. Taedoumg

Department of Biology, University of Yaoundé, Yaoundé,

Cameroon

F. Schrodt

Max Planck Institute for Biogeochemistry, Jena, Germany

F. Schrodt

iDiv, German Centre for Integrative Biodiversity Research Halle, Jena-Leipzig, Germany
} 


\section{Introduction}

Forests and savannas are the dominant vegetation types of tropical regions (Walter and Mueller-Dombois 1971) and differ fundamentally in their structural characteristics and species composition (Torello-Raventos et al. 2013). Tree species associated with forest vs. savanna differ in numerous physiological characteristics, such as fire survivorship (Hoffmann et al. 2009; Ratnam et al. 2011), as well as in their wood and foliar characteristics (Gotsch et al. 2010; Hoffmann et al. 2005; Rossatto et al. 2013; Schrodt et al. 2014). We have, however, an incomplete knowledge on how the species differ in photosynthesis characteristics, especially in relation to nutrient availability. Although it does now seem clear that although tropical forests are more productive and comprise larger $\mathrm{C}$ stocks than tropical savannas, they tend to have lower maximum photosynthetic $\mathrm{C}$ assimilation rates per area of leaf area (Bloomfield et al. 2014; Domingues et al. 2010; Hoffmann et al. 2005; Rossatto et al. 2013).

Although it is well established that photosynthetic capacity can be modulated by leaf $\mathrm{N}$ concentrations (Evans 1989; Field and Mooney 1986), in the tropics, where soils are often old and weathered, P limitation may be more typical (Reich and Oleksyn 2004; Reich et al. 2009), with links to stand-level productivity (Mercado et al. 2011; Quesada et al. 2012). On the basis of several lines of evidence, it has, however, also been suggested that, in contrast to tropical forests, savannas may be more likely to be limited by $\mathrm{N}$ than P (Lloyd et al. 2009).

Our earlier work from West Africa demonstrated that, depending on their relative concentrations in the leaf tissue, both Rubisco activity and electron transport activity of African savanna and forest trees can potentially be limited by either $\mathrm{N}$ or $\mathrm{P}$ (Domingues et al. 2010). But in that study interpretations of forest/savanna differences were complicated by savanna measurements from a wide range of precipitation regimes across soil types that were extremely diverse.

Here we report on work from a naturally occurring forest/savanna mosaic in Central Cameroon where we investigate photosynthetic and associated foliar trait

\section{E. M. Veenendaal}

Centre for Ecosystem Studies, University of Wageningen,

Wageningen, The Netherlands

\section{S. Lewis}

Department of Geography, University College London, London, UK

\section{J. Lloyd}

Department of Life Sciences, Imperial College London, Silwood Park Campus, Buckhurst Road, Ascot, Berkshire SL5 7PY, UK characteristics of trees and shrubs for forest and savanna species growing in close proximity and thus the same climatic regime. We aimed to test the hypotheses that under similar climatic conditions in a zone of transition:

1. Scaling between foliar $\mathrm{N}$ and $\mathrm{P}$, and its relationship with photosynthesis, is different for forest and savanna species.

2. Species growing in savannas show more indications of $\mathrm{N}$ limitation than forest species (which would, in turn, be more likely to be limited by $\mathrm{P}$ ).

\section{Materials and methods}

Study location

Measurements were made during the end of the 2007 wet season (October/December) at the Mbam-Djerem National Park, central Cameroon (Electronic Supplementary Material Fig. S1). The area encompasses a transitional zone between the Guinea-Congo/Sudan formations (Maisels 2004; White 1983) where savannas co-exist with tall canopy forest and gallery forest in a mosaic characterised by relatively sharp boundaries (Mitchard et al. 2009). Mean annual precipitation is estimated at about $1.6 \mathrm{~m} \mathrm{year}{ }^{-1}$ (Hijmans et al. 2005).

\section{Study plots}

Measurements were made in seven permanent 1-ha plots chosen to contain three vegetation groupings recognizable on the basis of structure and species composition, as classified by Torello-Raventos et al. (2013), viz.: (1) 'long-grass savanna woodland' (three plots; MDJ-02, MDJ-04 and MDJ-08); (2) three plots within the broad 'forest' groupings (MDJ-01, MDJ-03 and MDJ-07); and finally, (3) 'transitional forest' as represented by a single plot (MDJ-05). This plot was once savanna, but has recently been invaded by forest species as described for our study area (Mitchard et al. 2011). For the interested reader, photographs of this site as well as MDJ04 (long-grass savanna) and the forested MDJ-01 and MDJ-03 are provided in Fig. 6 of Torello-Raventos et al. (2013).

Site characterisation

Biodiversity indices and measurements of plot structure were determined as detailed in Torello-Raventos et al. (2013). Soil sampling and associated measurements were made as described in Quesada et al. (2010) and Veenendaal et al. (2014). 


\section{Gas exchange characteristics}

Sampling leaves on excised upper canopy branches with the assistance of a tree climber, data were obtained from 196 leaves fully exposed to the sun sampled from 69 individuals representing 42 species of adult perennial C3 trees and shrubs. Within each plot the quantitatively dominant species were selected, and measurements made for photosynthetic capacity using a LI-COR-6400 portable photosynthesis system $\left(A-C_{\mathrm{i}}\right.$ curves at high photon irradiance), leaf nutrients and leaf mass per unit area $\left(M_{\mathrm{a}}\right)$. Methodological details follow Domingues et al. (2010), with a simple modification introduced for estimation of the two key photosynthetic capacity parameters $\left(V_{\mathrm{cmax}}\right.$, the maximum rate of carboxylation and $J_{\max }$, the maximum rate of electron transport) optionally incorporating a mesophyll conductance term $\left(g_{\mathrm{m}}\right)$ into the parameter estimation routine. The parameter $g_{\mathrm{m}}$ is difficult to estimate from $\mathrm{CO}_{2}$ response curves and the approach adopted in the present work followed two steps. A curve fit based on $\mathrm{CO}_{2}$ concentrations at the intercellular air spaces $\left(C_{\mathrm{i}}\right)$ as reported in Domingues et al. (2010) was performed first to generate initial values of the photosynthetic capacity parameters $\left(V_{c m a x} C_{i}\right.$ and $J_{\max -C_{i}}$. Next, a second curve fit was performed incorporating $g_{\mathrm{m}}$ in order to calculate $\mathrm{CO}_{2}$ concentrations at the sites of carboxylation $\left(C_{\mathrm{c}}\right)$ using the $V_{c m a x} C_{i}$ and $J_{\max -C_{i}}$ values as a starting point for the iteration process. To make our data comparable, the parameter fits for $V_{\mathrm{cmax}}$ and $J_{\max }$, as estimated from $A-C_{\mathrm{i}}$ curves at ambient temperatures (typically $28-33{ }^{\circ} \mathrm{C}$ ), were scaled to a reference temperature $\left(25^{\circ} \mathrm{C}\right)$ as described in Bernacchi et al. (2001).

Usually three replicates (leaves) were sampled from each individual plant sampled in this study, and up to three, but sometimes one or two individuals of the same species, were sampled at a given plot (Electronic Supplementary Material Table S1). When possible, measurements were taken directly from tree branches, but often branches were detached from trees and smaller stems were then immediately re-cut under water.

\section{Statistical and modelling analysis}

For statistical comparisons of leaf traits among plots, species' averages within each plot were computed after first taking averages from replicated samples of individual plants. Statistical inferences on the relationships of photosynthetic capacity parameters and associated leaf traits (nutrients and/or structure) were based on both simple and multiple linear regressions using values derived from determinations on individual leaves. Data were $\log _{10}$ transformed before standardized major axis (SMA) (Warton et al. 2006) analyses but not before the application of an area version of a dual-limitation model of $\mathrm{N}$ and $\mathrm{P}$

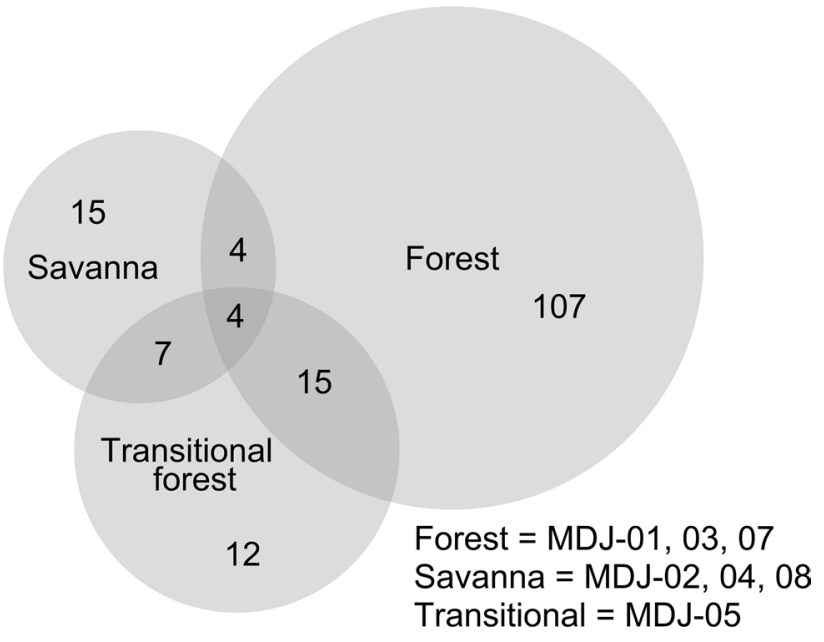

Fig. 1 Venn-Euler diagram showing the abundance of tree species across sample plots considered as 'forest', 'savanna' and 'transitional forest' according to the classification of Torello-Raventos et al. (2013). Numbers refer to number of individual species

introduced by Domingues et al. (2010) and here employed on an area basis viz.

$V_{\max }=\min \left\{\begin{array}{c}a_{\mathrm{N}}+b_{\mathrm{N}}[N]_{\mathrm{a}} \\ a_{\mathrm{P}}+b_{\mathrm{P}}[P]_{\mathrm{a}}\end{array}\right\}$,

where $V_{\max }$ is either $V_{\text {cmax }}$ or $J_{\max }, a_{\mathrm{N}}$ and $a_{\mathrm{P}}$ are intercepts and $b_{\mathrm{N}}$ and $b_{\mathrm{P}}$ are slopes empirically derived from fitting the model to the data. Model comparisons were based on evaluations of Akaike information criteria (AIC) and Bayesian information criteria (BIC). Bootstrapping analysis (Chernick and LaBudde 2011) was applied in order to derive confidence intervals for parameters which originated from the application of the dual-limitation model (Eq. 1). All statistical analysis was conducted using the statistical environment R (R Development Core Team 2011).

For these $C_{\mathrm{i}}$-based analyses of the nutrient dependencies of $V_{\text {cmax }}$ and $J_{\max }$ we also included data from the West African transect ZOT in Ghana sampled with an identical methodology (Domingues et al. 2010) so as to increase both the sample size and the variation of $\mathrm{N}$ and $\mathrm{P}$ observed.

\section{Results}

Assignment of species to the forest or savanna guilds

As described in detail by Torello-Raventos et al. (2013), species found within the forest-savanna ecotone can usually be classified as belonging to 'forest' or 'savanna' based on their observed distribution, although a small degree of overlap inevitably occurs. This is illustrated in Fig. 1 where the distributions of tree/shrub species (stem diameter at 
Table 1 Soil and vegetation properties of the study plots

\begin{tabular}{|c|c|c|c|c|c|c|c|}
\hline & Forest & & & Transition & Savanna & & \\
\hline Location & MDJ-01 & MDJ-03 & MDJ-07 & MDJ-05 & MDJ-02 & MDJ-04 & MDJ-08 \\
\hline Latitude & $6.1683 \mathrm{~N}$ & $5.984 \mathrm{~N}$ & $6.007 \mathrm{~N}$ & $5.980 \mathrm{~N}$ & $6.164 \mathrm{~N}$ & $5.999 \mathrm{~N}$ & $6.213 \mathrm{~N}$ \\
\hline Longitude & $12.825 \mathrm{E}$ & $12.869 \mathrm{E}$ & $12.887 \mathrm{E}$ & $12.869 \mathrm{E}$ & $12.824 \mathrm{E}$ & $12.868 \mathrm{E}$ & $12.749 \mathrm{E}$ \\
\hline \multicolumn{8}{|l|}{ Biodiversity measures } \\
\hline Number of Families & 25 & 30 & 28 & 21 & 15 & 12 & 12 \\
\hline Number of Genera & 43 & 56 & 54 & 32 & 23 & 16 & 19 \\
\hline Number of Species & 59 & 79 & 69 & 44 & 23 & 19 & 19 \\
\hline Shannon index & 3.05 & 3.09 & 3.42 & 2.53 & 2.34 & 2.02 & 2.15 \\
\hline \multicolumn{8}{|l|}{ Vegetation structure } \\
\hline Basal area, $\mathrm{m}^{2} \mathrm{ha}^{-1}$ & 35.6 & 25.6 & 25.6 & 14.0 & 4.3 & 5.9 & 8.1 \\
\hline Canopy area index, $\mathrm{m}^{2} \mathrm{~m}^{-2}$ & 3.24 & 2.98 & 1.75 & 2.85 & 0.45 & 0.36 & 0.48 \\
\hline Tree density, ha $^{-1}$ & 611 & 467 & 465 & 684 & 136 & 213 & 241 \\
\hline \multicolumn{8}{|c|}{ Soil physical and chemical properties $(0.0-0.3 \mathrm{~m})$} \\
\hline Sand fraction & 0.41 & 0.65 & 0.67 & 0.58 & 0.28 & 0.56 & 0.59 \\
\hline Silt fraction & 0.38 & 0.23 & 0.16 & 0.18 & 0.33 & 0.16 & 0.28 \\
\hline Clay fraction & 0.22 & 0.12 & 0.18 & 0.25 & 0.39 & 0.28 & 0.13 \\
\hline $\mathrm{pH}\left(\mathrm{H}_{2} \mathrm{O}\right)$ & 6.53 & 4.88 & 4.70 & 4.50 & 5.32 & 4.92 & 5.81 \\
\hline$[\mathrm{N}], \mathrm{mg} \mathrm{g}^{-1}$ & 1.49 & 0.71 & 0.68 & 0.80 & 1.56 & 0.62 & 0.72 \\
\hline$[\mathrm{C}], \mathrm{mg} \mathrm{g}^{-1}$ & 19.4 & 8.6 & 9.0 & 12.0 & 26.5 & 9.8 & 11.5 \\
\hline $\mathrm{C} / \mathrm{N}$ ratio & 11.6 & 12.2 & 12.6 & 15.0 & 17.2 & 15.7 & 15.2 \\
\hline Total $\mathrm{P}, \mu \mathrm{g} \mathrm{g}^{-1}$ & 977 & 307 & 738 & 576 & 997 & 316 & 364 \\
\hline ECEC, mmol eq kg ${ }^{-1}$ & 21.1 & 10.5 & 7.3 & 1.6 & 9.3 & 5.2 & 16.4 \\
\hline \multicolumn{8}{|c|}{ Leaf traits (mean \pm standard deviation) } \\
\hline$M_{\mathrm{a}}, \mathrm{g} \mathrm{m}^{-2}$ & $80 \pm 31$ & $97 \pm 26$ & $109 \pm 21$ & $113 \pm 41$ & $136 \pm 23$ & $127 \pm 26$ & $135 \pm 32$ \\
\hline$V_{\mathrm{cmax}}, \mu \mathrm{mol} \mathrm{m} \mathrm{s}^{-2} \mathrm{~s}^{-1}$ & $39.2 \pm 13.6$ & $42.3 \pm 12.2$ & $45.7 \pm 12.1$ & $44.8 \pm 8.3$ & $54.6 \pm 11.8$ & $39.2 \pm 9.2$ & $27.8 \pm 0.1$ \\
\hline$J_{\max ,} \mu \mathrm{mol} \mathrm{m}{ }^{-2} \mathrm{~s}^{-1}$ & $76.8 \pm 20.5$ & $79.3 \pm 19.5$ & $88.2 \pm 17.8$ & $81.0 \pm 18.6$ & $87.6 \pm 17.5$ & $67.9 \pm 12.3$ & $47.5 \pm 10.2$ \\
\hline$N_{\mathrm{a}}, \mathrm{g} \mathrm{m}^{-2}$ & $1.97 \pm 0.55$ & $2.26 \pm 0.67$ & $2.13 \pm 0.46$ & $2.12 \pm 0.56$ & $2.67 \pm 1.39$ & $1.48 \pm 0.27$ & $1.44 \pm 0.06$ \\
\hline$P_{\mathrm{a}}, \mathrm{g} \mathrm{m}^{-2}$ & $0.12 \pm 0.05$ & $0.10 \pm 0.03$ & $0.09 \pm 0.02$ & $0.10 \pm 0.03$ & $0.16 \pm 0.08$ & $0.13 \pm 0.04$ & $0.12 \pm 0.07$ \\
\hline$\delta^{13} \mathrm{C}, \%$ & $-29.8 \pm 1.2$ & $-30.0 \pm 1.0$ & $-30.6 \pm 1.2$ & $-30.0 \pm 0.9$ & $-30.5 \pm 0.3$ & $-30.3 \pm 0.3$ & $-29.3 \pm 0.1$ \\
\hline
\end{tabular}

ECEC Effective cation exchange capacity, $M_{\mathrm{a}}$ leaf mass per unit area, $V_{25}$ estimated maximum rate of Rubisco limited carboxylation at $25^{\circ} \mathrm{C}$, $J_{25}$ estimated maximum rate of electron transport at $25^{\circ} \mathrm{C}, N_{\mathrm{a}}$ leaf nitrogen per unit area, $P_{\mathrm{a}}$ leaf phosphorus per unit area

breast height $>0.1 \mathrm{~m}$ ) are represented using a Venn-Euler diagram. Here, the number of plant species found in more than one vegetation type is represented numerically and proportionally by the areas of intersection among the circles. Only eight out of the 164 species observed in the seven study plots occurred in both forest and savanna [see also Table E1 of the Supplementary Information of TorelloRaventos et al. (2013)]. The transitional forest (MDJ-05) did, however, contain many savanna species, as well as several unique species not found in the nearby forest or savanna plots.

\section{Stand properties}

Consistent with Fig. 1, a larger variety of families, genera and species were found at the forest sites (Table 1). Not surprisingly, the forest plots also had larger stem density and larger basal area (Table 1). The transitional forest plot MDJ-05 had the highest stem density but that added to a low total basal area (Table 1). That plot also had a relatively large number of dead standing savanna trees (data not shown).

Upper layer soil physical and chemical properties $(0.0$ $0.3 \mathrm{~m}$ ) also varied substantially amongst plots but-with the exception of soil $\mathrm{C} / \mathrm{N}$ ratio-not consistently between the two main vegetation formation types (Table 1). As an example, effective cation exchange capacity (the sum of exchangeable bases plus $\mathrm{Al}$ ) was highest at plot MDJ01 (forest) and MDJ-08 (savanna) with other forest and savanna plots having only about one-third of these values while total soil $\mathrm{P}$ varied between 307 and $977 \mu \mathrm{g} \mathrm{g}^{-1}$ for the forest plots and 316 and $997 \mu \mathrm{g} \mathrm{g}^{-1}$ for the savanna plots. 
Fig. 2 Partitioning of the total variance between plots, species, individual trees. The residual term includes between-leaf variation and experimental error. $M_{\mathrm{a}}$ Leaf mass per unit area, $N_{\mathrm{a}} \mathrm{N}$ per unit leaf area, $P_{\mathrm{a}} \mathrm{P}$ per unit leaf area, $A_{\max (a)}$ net $\mathrm{CO}_{2}$ assimilation rate per unit leaf area at saturating light and $\left[\mathrm{CO}_{2}\right]$
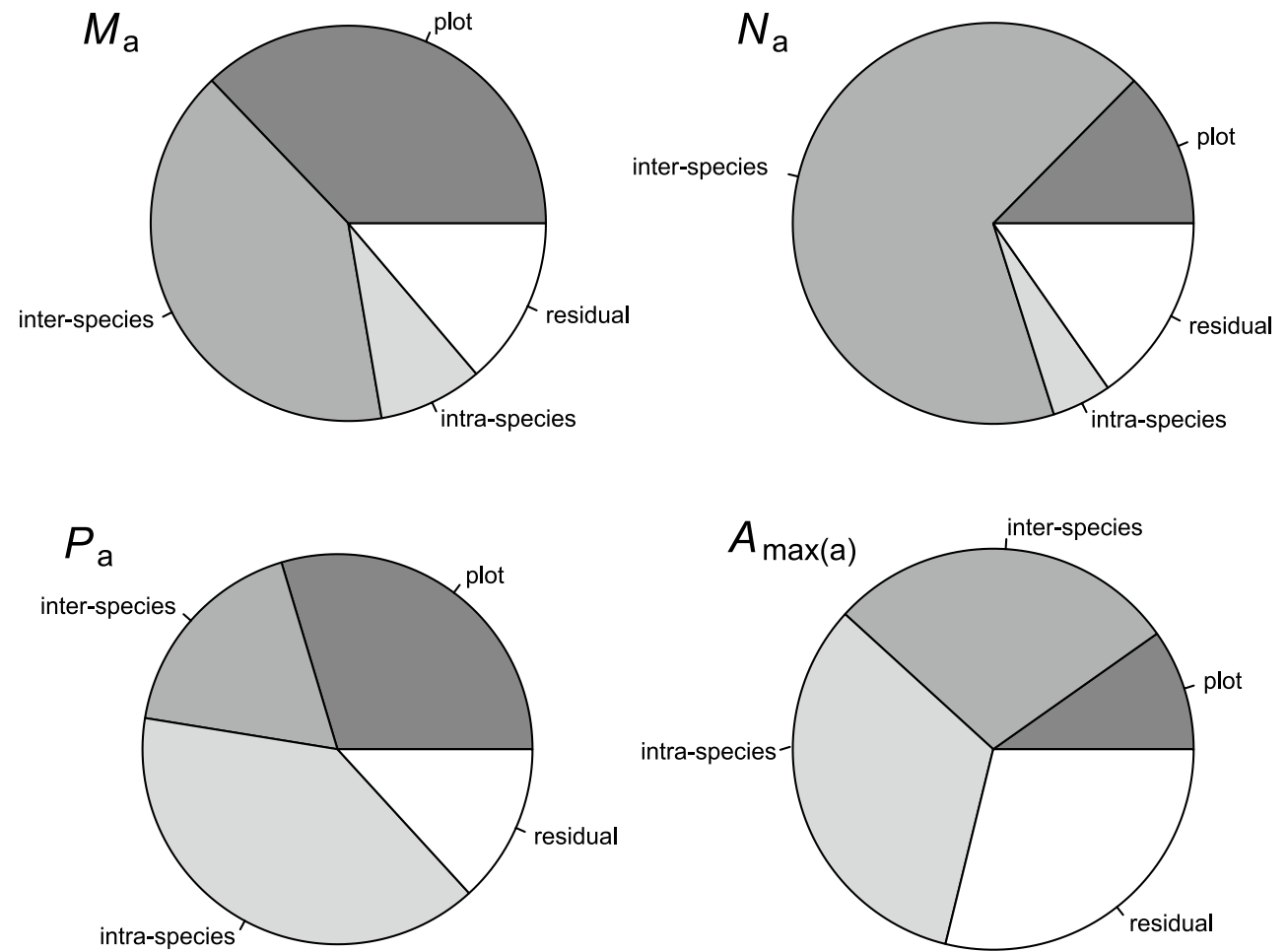

\section{Leaf traits}

A partitioning of the measured trait variation between plots, species, individual trees, and a residual component (representing the average variation between leaves within any given tree plus any experimental error) is shown in Fig. 2. For $M_{\mathrm{a}}$ and $\mathrm{N}$ per unit area $\left(N_{\mathrm{a}}\right)$, this shows most of the variation not due to plot location was attributable to species identity, with the proportion of variation between trees of the same species and 'residual variation'(i.e. attributable to within-tree variability and experimental error) being relatively small. By contrast, for $P_{\mathrm{a}}$ and the light $/ \mathrm{CO}_{2}$ saturated assimilation rate $\left(A_{\max (a)}\right)$ most of this variation was within species or within individual trees themselves (Fig. 2). In view of this inconsistent pattern of variation among traits, we undertook all analyses on a leaf-wise basis rather than deriving individual tree means or some sort of (often necessarily cross-plot) species' average value.

Despite often considerable overlap between leaf attributes found in forest versus savanna, some differences are striking (Fig. 3). For example, forest leaves typically had a lower $M_{\mathrm{a}}$, higher $N_{\mathrm{m}}$, a lower $P_{\mathrm{a}}$ and a higher N:P ratio. Also shown in Fig. 3 are the equivalent data for forest and savanna from the ZOT component of the West African study of Domingues et al. (2010). This shows some interesting differences, the statistically significant of which are evaluated-along with a comparison for the Cameroon forest species with South American forest-in Table 2. Taken together, Table 2 and Fig. 4 show several intra- and crosscontinental differences.

Focussing first on the current study (comparison 1) forest $(\mathbb{F})$ leaves had a higher $N$ content than savanna $(\mathbb{S})$ leaves on both an area and a mass basis. The effect of vegetation formation type $(\mathbb{V})$ on foliar $\mathrm{P}$ contents was, however, rather small. Despite the differences between $\mathbb{F}$ and $\mathbb{S}$ in both $N_{\mathrm{a}}$ and $P_{\mathrm{a}}$ (which we also point out were of opposite sign), there was no effect of $\mathbb{V}$ on $A_{\text {sat(a) }}$ (Table 2: comparison 1).

Also in Table 2 (comparison 2) we compare the significance of differences between forest leaves from this study in Cameroon with the earlier study from West Africa. With the same methodology we find West African ZOT forest leaves to have had significantly lower $M_{\mathrm{a}}, N_{\mathrm{a}}$ and $A_{\text {sat(a) }}$ than for Cameroon, but with about the same $\mathrm{P}, \mathrm{N}$ and $A_{\text {sat }}$ on a mass basis.

The corresponding comparison for savanna also showed West African leaves to have a lower $M_{\mathrm{a}}$, but with their $\mathrm{N}$ concentration and photosynthetic rates on a mass basis no lower than for Cameroon. Nevertheless, because of the lower $M_{\mathrm{a}}$ in West Africa, $A_{\text {sat(m) }}$ were higher; this was also associated with higher $P_{\mathrm{m}}$ and $N_{\mathrm{m}}$ (Table 2).

Finally, to help gain a broader perspective we compared our Cameroon forest data with those obtained from the forests of the Amazon Basin (Fyllas et al. 2009, 2012). The latter study classified Amazonian sites into two soil fertility groups on the basis of their soil chemical properties and demonstrated that 'low nutrient soil' forests have 

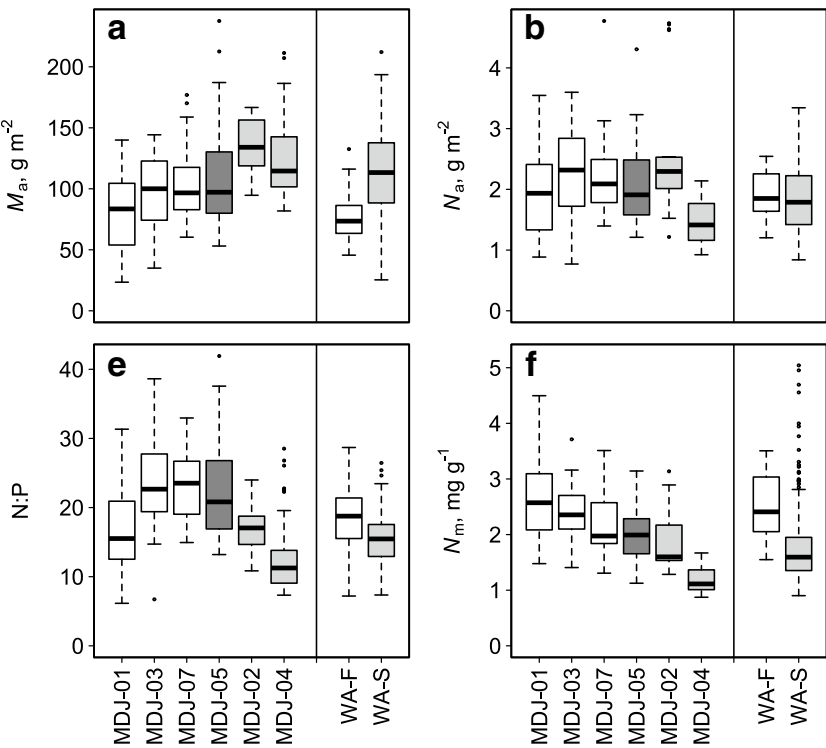

Fig. 3 Statistical comparison of leaf attributes of forest (white bars), savanna (light grey) and transitional forest (dark grey) sampled in central Cameroon. Also shown (right of vertical line) are forest (WA$F)$ and savanna data $(W A-S)$ from a previous study in West Africa (Domingues et al. 2010). a $M_{\mathrm{a}} ; \mathbf{b} N_{\mathrm{a}} ; \mathbf{c} P_{\mathrm{a}}$; d net $\mathrm{CO}_{2}$ assimilation

lower leaf $\mathrm{N}$ and $\mathrm{P}$ on both an area and mass basis, and also higher N:P ratios than those of our Cameroon study area (Table 2). On the other hand, leaves from sites classified as 'high nutrient soil' by Fyllas et al. (2009) were very similar in composition to our Cameroon sites on both a mass and area basis. We therefore conclude that the African forest species sampled here are quite similar in their $\mathrm{N}$ and $\mathrm{P}$ concentrations to trees occurring on the more fertile soils of the Amazon Basin. As $M_{\mathrm{a}}$ are, on average, similar, this is true on both an area and mass basis, with the African forests studied here differing from the Amazon Basin forests on lower nutrient status soils mostly in terms of a higher foliar P status.

\section{Bivariate relationships}

Concentrating again on the Cameroon data, Fig. 4 shows the associations between $A_{\text {sat(a) }}, M_{\mathrm{a}}, N_{\mathrm{a}}$ and $P_{\mathrm{a}}$ wherenoting that all savanna species were deciduous-we have further differentiated forest species according to their leaf habit (evergreen vs. deciduous) as in Schrodt et al. (2014).

Although the relationship between $A_{\max (a)}$ and $M_{\mathrm{a}}$ was not significant for either of the forest habit types, for the deciduous savanna species $\left(\mathbb{S}_{\mathrm{d}}\right)$, there was a statistically significant positive relationship $(p=0.038)$. Compared to the two forest types there was a (common) SMA slope of $0.13 \mu \mathrm{mol} \mathrm{CO}_{2} \mathrm{~g}^{-1}$ dry weight $\mathrm{s}^{-1}$ but with a clear
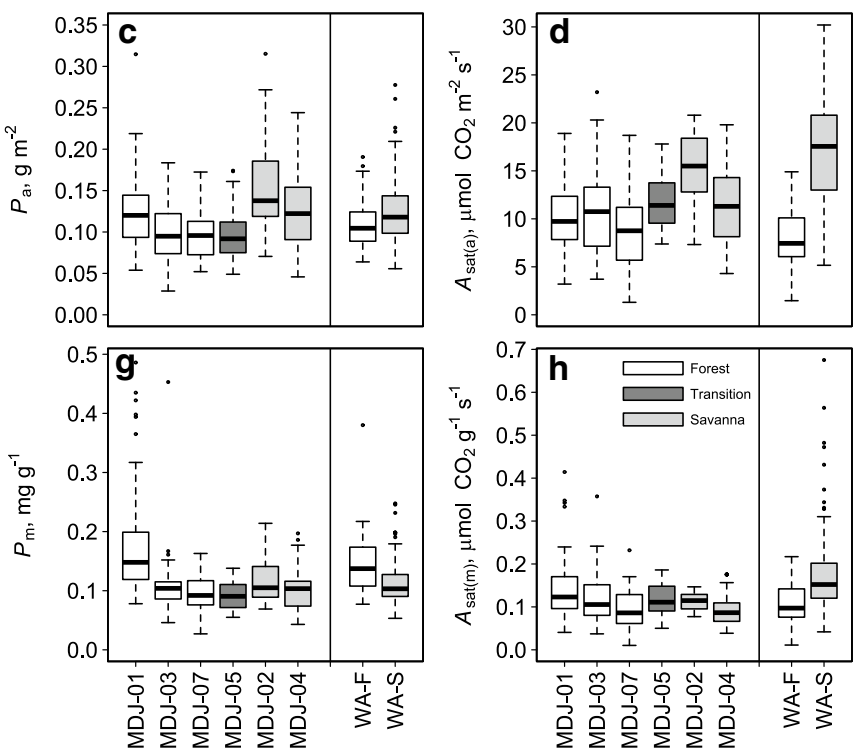

rate per unit leaf area at saturating light and ambient $\left[\mathrm{CO}_{2}\right]\left[A_{\text {sat(a) }}\right]$; e leaf N/P ratio $\left(N: P ; \mathrm{g} \mathrm{g}^{-1}\right) ; \mathbf{f} \mathrm{N}$ per unit leaf mass $\left(N_{\mathrm{m}}\right) ; \mathbf{g} \mathrm{P}$ per unit leaf mass $\left(P_{\mathrm{m}}\right) ; \mathbf{h}$ net $\mathrm{CO}_{2}$ assimilation rate per unit leaf mass area at saturating light and ambient $\left[\mathrm{CO}_{2}\right]\left[A_{\mathrm{sat}(\mathrm{m})}\right]$; for other abbreviations, see Fig. 2

difference in intercept (Fig. 4a). That is to say, for any given $M_{\mathrm{a}}, \mathbb{S}_{\mathrm{d}}$ tend to have a consistently lower $A_{\text {sat(a) }}$ than either of the forest habit types. When examined as a function of $N_{\mathrm{a}}$ (Fig. 4b), all three habitat groupings showed statistically significant relationships $(p<0.10)$ with $\mathbb{S}_{\mathrm{d}}$ having a photosynthetic rate about $2.5 \mu \mathrm{mol} \mathrm{CO} \mathrm{Cm}^{-2} \mathrm{~s}^{-1}$ greater than the forest species at any given $N_{\mathrm{a}}$ (common slope of $5.90 \mu \mathrm{mol} \mathrm{CO} \mathrm{Cg}^{-1} \mathrm{~N} \mathrm{~s}^{-1}$ ). Relationships between $A_{\text {sat(a) }}$ and $P_{\mathrm{a}}$ were significant only for $\mathbb{S}_{\mathrm{d}}$ (slope $=74 \mu \mathrm{mol} \mathrm{CO}_{2}$ $\left.\mathrm{g}^{-1} \mathrm{P} \mathrm{s}^{-1} ; p<0.05\right)$, with data for the forest evergreen leaves $\left(\mathbb{F}_{\mathrm{e}}\right)$ even suggesting a (non-significant) negative relationship (Fig. 4c). The $N_{\mathrm{a}}: P_{\mathrm{a}}$ relationship was statistically significant for both deciduous types, with a clear difference in elevation: at any given $N_{\mathrm{a}}, \mathbb{S}_{\mathrm{d}}$ typically had a $P_{\mathrm{a}}$ about $0.04 \mathrm{~g} \mathrm{~m}^{-2}$ greater than their deciduous forest counterparts $\left(\mathbb{F}_{\mathrm{d}}\right)$ (Fig. $\left.4 \mathrm{~d}\right)$.

For all four bivariate relationships investigated there were no clear indications of trees sampled from transitional vegetation being distinct from those of either the (non-transitional) forest or savanna vegetation types. Overall, we conclude from Fig. 4 that the strongest relationship is between $A_{\text {sat(a) }}$ and $N_{\text {a }}$ with deciduous savanna species were markedly different from both forest types: in particular, they exhibited a substantially higher mean $A_{\text {sat(a) }}$ for any given $N_{\mathrm{a}}$. Moreover, unlike forest species, for savanna species there is also a dependence of $A_{\text {sat(a) }}$ on $P_{\mathrm{a}}$. At any given $N_{\mathrm{a}}, P_{\mathrm{a}}$ was higher in the leaves of savanna trees. 


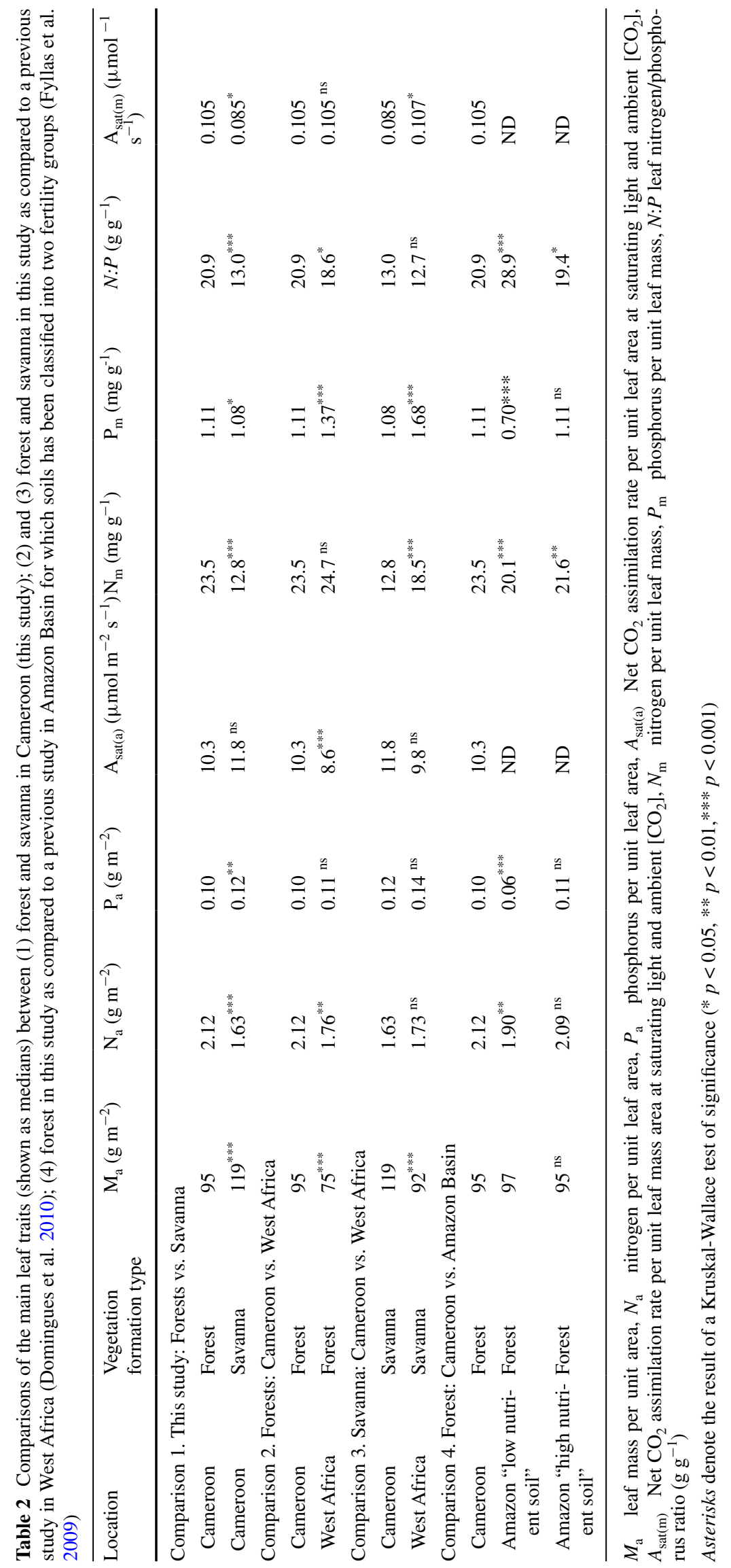


Fig. 4a-d Bivariate plots of observed relationships between area-based measures of lightsaturated photosynthetic rate $\left[A_{\text {sat(a) }}\right], \mathrm{N}$ and P. Deciduous forest (squares), evergreen forest (circles) and savanna (triangles) with open, grey and black symbols indicating individuals in forest, transition and savanna environments, respectively. Lines are standard major axis (SMA) regression fits for forest deciduous (black line), forest evergreen (grey line), and savanna deciduous leaves (dotted line)
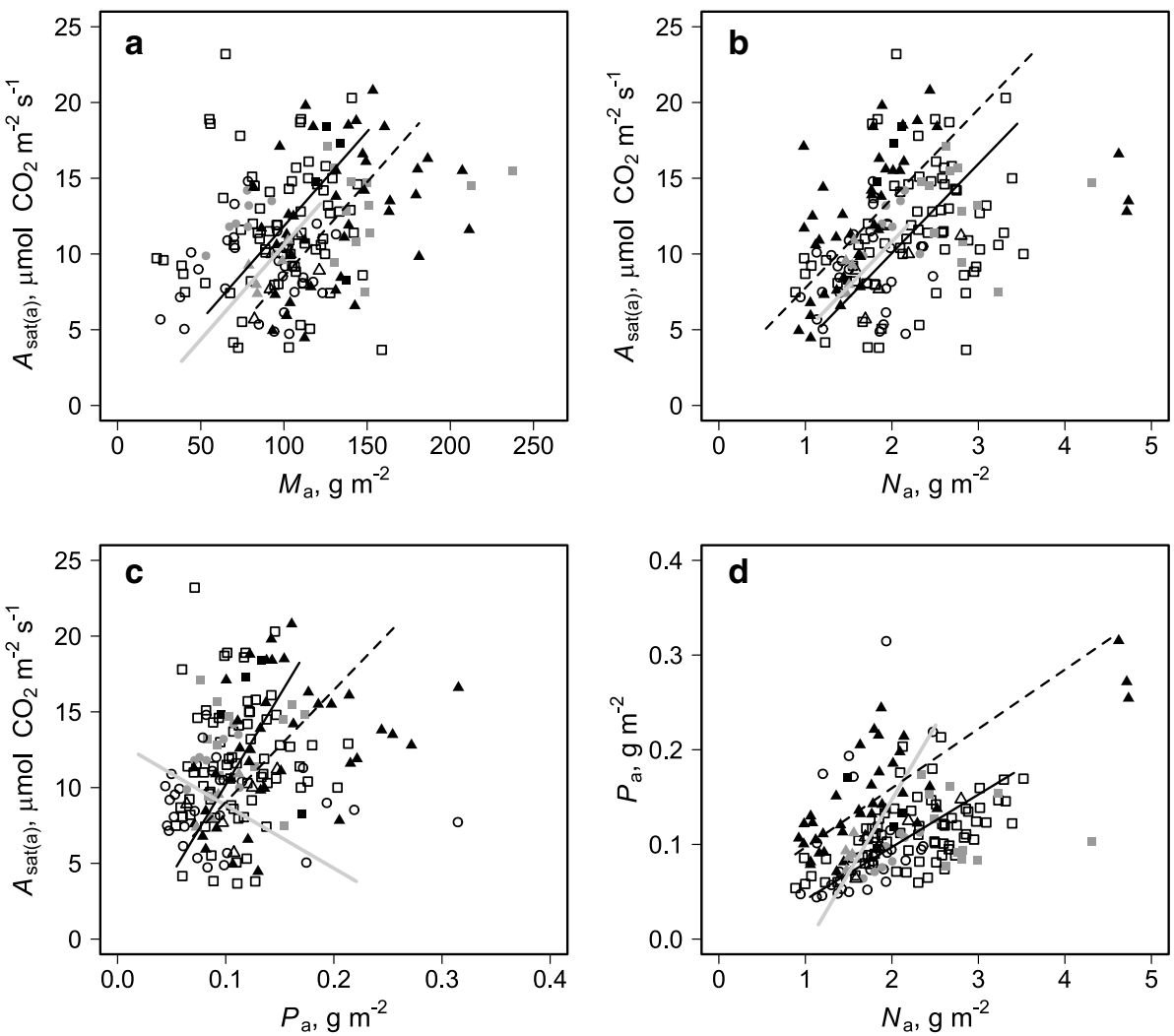

Variations in Rubisco and electron transport capacities in relation to $\mathrm{N}$ and $\mathrm{P}$

Although as noted in the Materials and methods one would ideally like to model variations in both $V_{\text {cmax }}$ and $J_{\max }$ in terms of the partial pressure of $\mathrm{CO}_{2}$ in the chloroplast $\left(C_{\mathrm{c}}\right)$, this requires some reliable measure of the leaf 'internal' conductance $\left(g_{\mathrm{m}}\right)$. Nevertheless, for the study here, both $V_{\text {cmax }}$ and $J_{\max }$ were eventually simply estimated from the $A-C_{\mathrm{i}}$ curve with the associated kinetic constants for $g_{\mathrm{m}}=\infty$ applied (Von Caemmerer 2000). This decision was made on the basis of: (1) there being no significant relationship between our curve-fitting-derived estimates of $g_{\mathrm{m}}$ and traits previously considered to covary with it [viz. $M_{\mathrm{a}}$ or $\delta^{13} \mathrm{C}$ (Niinemets (1999)]; (2) there being no consistent differences in apparent $g_{\mathrm{m}}$ between vegetation types; and (3) there being little systematic difference observed between $C_{\mathrm{c}^{-}}$and $C_{\mathrm{i}^{-}}$(intercellular spaces) based estimates of these photosynthetic parameters (Electronic Supplementary Material Fig. S1).

Details of area-based photosynthesis-nutrient relationships so derived for simple ordinary least squares (OLS) linear models and the more complex dual-limitation model of Eq. 1 are shown in Table 3. For $F_{e}$ the best fit according to the AIC was the simple linear model wherein $V_{25}$ is a simple function of $N_{\mathrm{a}}\left(r^{2}=0.17, p=0.002\right)$, with the $\mathrm{BIC}$ - similar to the AIC but with more severe penalties for extra terms-giving the same result. Of the linear models, a simple dependence of $V_{25}$ on $N_{\mathrm{a}}$ also gave the best fit for $\mathbb{F}_{\mathrm{d}}$ according to the BIC $\left(r^{2}=0.21, p=0.001\right)$ but with the alternative dual-limitation model (Domingues et al. 2010) being marginally better according to the AIC $\left(r^{2}=0.23\right.$, $p=0.001)$. Note, however, that in this model the $P_{\mathrm{a}}$ term is negative, implying an inhibitory effect of $\mathrm{P}$ on $V_{25}$. Overall, the results for the two forest types were similar, so when they were combined there was, not surprisingly, an increase in the correlation coefficient values for the $N_{\mathrm{a}}$ based models with the AIC suggesting the dual-limitation model $\left(r^{2}=0.29\right)$ to be marginally superior to the simple $N_{\mathrm{a}}$-based linear model (which was in turn unambiguously favoured when considering the BIC). Note that in no case was there any indication for a role for $P_{\mathrm{a}}$ as a modulator of $V_{25}$ when considered on its own $\left(r^{2} \leq 0.01\right)$ for forest trees, with $P_{\mathrm{a}}$ having only a marginal influence when considered in conjunction with $N_{\mathrm{a}}$.

By contrast, for $\mathbb{S}_{\mathrm{d}}$ it was found that $P_{\mathrm{a}}$ was nearly as good a predictor as $N_{\mathrm{a}}$ when considered on its own $\left(r^{2}=0.18\right.$ vs. 0.19$)$ and with the linear model fits including both terms being significantly better than either $N_{\mathrm{a}}$ or $P_{\mathrm{a}}$ on their own. Overall, the dual-limitation model was, however, found to be superior to the OLS models according to both the AIC and BIC $\left(r^{2}=0.30, p<0.001\right)$. Although a simple combination of the forest and savanna data suggest that the dual-limitation model is not the best when looking 
Table 3 Comparisons of predictive models of area based maximum carboxylation capacity $\left(V_{25}=V_{\text {cmax }}\right.$-area $\left.25{ }^{\circ} \mathrm{C} ; \mu \mathrm{mol} \mathrm{m} \mathrm{m}^{-2} \mathrm{~s}^{-1}\right)$ based on leaf nitrogen and/or phosphorus content

\begin{tabular}{|c|c|c|c|c|}
\hline Equation & $r^{2}$ & AIC & $\mathrm{BIC}$ & $p$ \\
\hline \multicolumn{5}{|l|}{ Forest evergreen } \\
\hline$V_{25}=16.43+11.72 N_{\mathrm{a}}$ & 0.17 & 371.35 & 377.14 & 0.002 \\
\hline$V_{25}=35.53+19.03 P_{\mathrm{a}}$ & 0.01 & 381.21 & 387.01 & 0.495 \\
\hline$V_{25}=16.49+12.50 N_{\mathrm{a}}-14.64 P$ & $D_{\mathrm{a}} 0.15$ & 373.05 & 380.77 & 0.007 \\
\hline $\begin{array}{l}V_{25}=28.22+5.82 N_{\mathrm{a}}- \\
134.72 P_{\mathrm{a}}+65.97 N_{\mathrm{a}} P_{\mathrm{a}}\end{array}$ & 0.15 & 374.04 & 383.70 & 0.013 \\
\hline $\begin{array}{l}V_{25}=\min \left(16.43+11.72 N_{\mathrm{a}}\right. \\
\left.50.23+24.52 P_{\mathrm{a}}\right)\end{array}$ & 0.15 & 374.35 & 385.01 & 0.037 \\
\hline \multicolumn{5}{|l|}{ Forest deciduous } \\
\hline$V_{25}=23.62+10.41 N_{\mathrm{a}}$ & 0.21 & 830.27 & 838.23 & $<0.001$ \\
\hline$V_{25}=42.80+39.09 P_{\mathrm{a}}$ & 0.00 & 854.61 & 862.58 & 0.323 \\
\hline$V_{25}=25.50+10.91 N_{\mathrm{a}}-26.49 P$ & $D_{\mathrm{a}} 0.20$ & 831.75 & 842.36 & $<0.001$ \\
\hline $\begin{array}{l}V_{25}= \\
\quad 7.71+19.37 N_{\mathrm{a}}+143.95 P_{\mathrm{a}}- \\
78.49 N_{\mathrm{a}} P_{\mathrm{a}}\end{array}$ & 0.21 & 831.76 & 845.03 & $<0.001$ \\
\hline $\begin{array}{l}V_{25}=\min \left(16.77+14.00 N_{\mathrm{a}}\right. \\
\left.\quad 57.83-32.13 P_{\mathrm{a}}\right)\end{array}$ & 0.23 & 829.26 & 843.53 & $<0.001$ \\
\hline \multicolumn{5}{|l|}{ Forest (evergreen and deciduous) } \\
\hline$V_{25}=18.61+12.03 N_{\mathrm{a}}$ & 0.27 & 1208.24 & 1217.39 & $<0.001$ \\
\hline$V_{25}=38.95+46.60 P_{\mathrm{a}}$ & 0.01 & 1255.86 & 1265.01 & 0.080 \\
\hline$V_{25}=19.60+12.45 N_{\mathrm{a}}-17.26 P$ & $D_{\mathrm{a}} 0.27$ & 1209.73 & 1221.93 & $<0.001$ \\
\hline $\begin{array}{l}V_{25}=11.02+16.96 N_{\mathrm{a}}+64.75 \\
\quad \mathrm{a}-41.37 N_{\mathrm{a}} P_{\mathrm{a}}\end{array}$ & $P 0.27$ & 1210.75 & 1226.00 & $<0.001$ \\
\hline $\begin{array}{l}V_{25}=\min \left(12.83+15.22 N_{\mathrm{a}}\right. \\
\left.57.43-34.33 P_{\mathrm{a}}\right)\end{array}$ & 0.29 & 1206.40 & 1222.65 & $<0.001$ \\
\hline \multicolumn{5}{|l|}{ Savanna (deciduous) } \\
\hline$V_{25}=26.22+8.25 N_{\mathrm{a}}$ & 0.19 & 779.04 & 786.89 & $<0.001$ \\
\hline$V_{25}=25.30+111.17 P_{\mathrm{a}}$ & 0.18 & 780.01 & 787.86 & $<0.001$ \\
\hline$V_{25}=22.20+5.27 N_{\mathrm{a}}+66.68 P_{\mathrm{c}}$ & a 0.23 & 775.52 & 785.98 & $<0.001$ \\
\hline $\begin{array}{l}V_{25}= \\
1.57+17.67 N_{\mathrm{a}}+167.62 P_{\mathrm{a}}- \\
57.46 N_{\mathrm{a}} P_{\mathrm{a}}\end{array}$ & 0.27 & 770.21 & 783.29 & $<0.001$ \\
\hline $\begin{array}{l}V_{25}=\min \left(34.87+5.83 N_{\mathrm{a}}\right. \\
\left.9.79+251.86 P_{\mathrm{a}}\right)\end{array}$ & $\mathbf{0 . 3 0}$ & 765.86 & 779.94 & $<0.001$ \\
\hline \multicolumn{5}{|c|}{ Forest and savanna (deciduous and evergreen) } \\
\hline$V_{25}=22.13+10.46 N_{\mathrm{a}}$ & 0.26 & 2151.39 & 2162.29 & $<0.001$ \\
\hline$V_{25}=36.03+57.33 P_{\mathrm{a}}$ & 0.04 & 2223.43 & 2234.33 & 0.001 \\
\hline$V_{25}=21.53+10.24 N_{\mathrm{a}}+8.83 P_{\mathrm{a}}$ & a 0.25 & 2153.07 & 2167.60 & $<0.001$ \\
\hline $\begin{array}{l}V_{25}=6.44+17.70 N_{\mathrm{a}}+118.70 I \\
\quad \mathrm{a}-51.98 N_{\mathrm{a}} P_{\mathrm{a}}\end{array}$ & $P 0.29$ & 2141.92 & 2160.10 & $<0.001$ \\
\hline $\begin{array}{l}V_{25}=\min \left(22.13+10.46 N_{\mathrm{a}}\right. \\
\left.\quad 75.85+19.52 P_{\mathrm{a}}\right)\end{array}$ & 0.25 & 2154.39 & 2173.56 & $<0.001$ \\
\hline
\end{tabular}

$N_{\mathrm{a}}$ nitrogen per unit leaf area $\left(\mathrm{g} \mathrm{m}^{-2}\right), P_{\mathrm{a}}$ phosphorus per unit leaf area $\left(\mathrm{g} \mathrm{m}^{-2}\right)$

Models addressed in detail in the "Results" and "Discussion" sections are highlighted in bold

for a common (cross-biome) relationship-in this case it being surpassed by a model containing linear functions of $N_{\mathrm{a}}$ and $P_{\mathrm{a}}$ and their interaction term $N_{\mathrm{a}}$ and $P_{\mathrm{a}}$-a simple analysis of AIC/BIC and/or the residual sum of squares (RSS) according to a procedure outlined in Lloyd et al. (1989) also shows that this combined (forest + savanna) model provides an inferior fit compared to when forest (i.e. $\mathbb{F}_{\mathrm{d}}$ and $\mathbb{F}_{\mathrm{e}}$ together) and savanna $\left(\mathbb{S}_{\mathrm{d}}\right)$ are considered separately $(p<0.001)$. That is to say, although for the forest species $V_{25}$ showed a simple dependency upon $N_{\mathrm{a}}$, for $\mathbb{S}_{\mathrm{d}}$ an additional role for $P_{\mathrm{a}}$ is clearly implicated.

A similar picture emerges when models for $J_{25}$ are sought with little evidence of a role for $P_{\mathrm{a}}$ as a modulating factor for either $\mathbb{F}_{\mathrm{d}}$ or $\mathbb{F}_{\mathrm{e}}$ and with $N_{\mathrm{a}}$ effects apparently dominant for these two forest types (Table 4). As for $V_{25}$ there is, however, a clear indication of a role for $\mathrm{P}$ for $\mathbb{S}_{\mathrm{d}}$, and with the dual-limitation model giving the best fit. Likewise, when all data are combined, then comparisons of either AIC, BIC or RSS with the individual models show that in any analyses of their $J_{25}$ nutrient dependencies, forest and savanna species need to be considered separately.

Fitting separate relationships for both forest and savanna, the resulting goodness of model fit is shown for both $V_{25}$ and $J_{25}$ in Electronic Supplementary Material, Fig. S3. This shows that in all cases, model predictions involved a much smaller degree of variation than suggested by the observations. An examination of model residuals in terms of the predictor variables $N_{\mathrm{a}}$ and $P_{\mathrm{a}}$ along with a range of other potentially confounding covariates such as $M_{\mathrm{a}}$ and area-based cations (see Electronic Supplementary Material, Figs. S4, S5) did not, however, suggest reasons for concern in terms of any traitspecific systematic bias for either $V_{25}$ or $J_{25}$. Also note that in Figs. S3 and S4 we have separately identified members of the Fabaceae which, although making up less than $5 \%$ of our data set, are also unusual in their foliar $\mathrm{N}$ and $\mathrm{P}$ characteristics (Fyllas et al. 2009), especially in relation to photosynthesis (Cernusak et al. 2011). There were, however, no indications from this study that members of this family behaved in any way different to the population sampled as a whole.

For both $V_{25}$ and $J_{25}$ the observed relationships with $N_{\mathrm{a}}$ and $P_{\mathrm{a}}$ are shown in Fig. 5. Here, for forest, we have shown the fitted lines for the modelled simple linear $N_{\mathrm{a}}$ dependencies for both $V_{25}$ and $J_{25}$ with the dual-limitation model predictions presented only for $\mathbb{S}_{\mathrm{d}}$. This differentiation has been made on the basis of a bootstrapping analysis (Chernick and LaBudde 2011), which showed that for both $V_{25}$ and $J_{25}$ the (apparently negative) $V_{25}$ and $P_{\mathrm{a}}$ terms were not significantly different from zero (see Table S2 in Electronic Supplementary Material) for both forest types, the implication of this being that $P_{\mathrm{a}}$ actually exerts no modulating role on the photosynthetic properties of both $\mathbb{F}_{\mathrm{d}}$ and $\mathbb{F}_{\mathrm{e}}$. For $V_{25}$ our model clearly suggests that savanna leaves with $N_{\mathrm{a}}<2.5 \mathrm{~g} \mathrm{~m}^{-2}$ have a higher carboxylation capacity than forest leaves at the same $N_{\mathrm{a}}$ (Fig. 5a).

Consistent with the simple linear $V_{25}=\mathrm{f}\left(N_{\mathrm{a}}\right)$ model being applied for the forest species, no fitted lines are 
Table 4 Comparisons of predictive models of area based maximum electron transport rate $\left(J_{25}=J_{\max }\right.$-area $\left.25^{\circ} \mathrm{C} ; \mu \mathrm{mol} \mathrm{m}^{-2} \mathrm{~s}^{-1}\right)$ based on leaf nitrogen and/or phosphorus content

\begin{tabular}{|c|c|c|c|c|}
\hline & $r^{2}$ & AIC & $\mathrm{BIC}$ & $p$ \\
\hline \multicolumn{5}{|l|}{ Forest evergreen } \\
\hline$J_{25}=32.69+21.14 N_{\mathrm{a}}$ & 0.18 & 426.88 & 432.68 & 0.001 \\
\hline$J_{25}=64.15+64.28[P]_{\mathrm{a}}$ & 0.02 & 436.24 & 442.03 & 0.181 \\
\hline$J_{25}=32.66+20.68 N_{\mathrm{a}}+8.58 P_{\mathrm{a}}$ & 0.16 & 428.85 & 436.58 & 0.005 \\
\hline$J_{25}=28.78+22.89 N_{\mathrm{a}}+48.23 P_{\mathrm{a}}-21.78 N_{\mathrm{a}} P_{\mathrm{a}}$ & 0.15 & 430.81 & 440.47 & 0.015 \\
\hline$J_{25}=\min \left(32.69+21.14 N_{\mathrm{a}} ; 78.99+64.40 P_{\mathrm{a}}\right)$ & 0.16 & 429.88 & 440.54 & 0.028 \\
\hline \multicolumn{5}{|l|}{ Forest deciduous } \\
\hline$J_{25}=40.42+19.60 N_{\mathrm{a}}$ & 0.24 & 946.15 & 954.12 & $<0.001$ \\
\hline$J_{25}=83.76-9.89 P_{\mathrm{a}}$ & -0.01 & 975.38 & 983.34 & 0.888 \\
\hline$J_{25}=49.03+21.89 N_{\mathrm{a}}-121.73 P_{\mathrm{a}}$ & 0.25 & 944.48 & 955.10 & $<0.001$ \\
\hline$J_{25}=25.94+32.89 N_{\mathrm{a}}+99.60 P_{\mathrm{a}}-101.93 N_{\mathrm{a}} P_{\mathrm{a}}$ & 0.26 & 945.34 & 958.61 & $<0.001$ \\
\hline$J_{25}=\min \left(30.05+24.93 N_{\mathrm{a}} ; 105.64-55.54 P_{\mathrm{a}}\right)$ & 0.26 & 945.12 & 959.39 & $<0.001$ \\
\hline \multicolumn{5}{|l|}{ Forest (evergreen and deciduous) } \\
\hline$J_{25}=35.21+21.30 N_{\mathrm{a}}$ & 0.29 & 1376.58 & 1385.73 & $<0.001$ \\
\hline$J_{25}=73.34+62.94 P_{\mathrm{a}}$ & 0.01 & 1428.19 & 1437.34 & 0.172 \\
\hline$J_{25}=38.25+22.58 N_{\mathrm{a}}-52.86 P_{\mathrm{a}}$ & 0.29 & 1376.94 & 1389.14 & $<0.001$ \\
\hline$J_{25}=15.48+34.54 N_{\mathrm{a}}+164.81 P_{\mathrm{a}}-109.80 N_{\mathrm{a}} P_{\mathrm{a}}$ & 0.29 & 1376.58 & 1391.83 & $<0.001$ \\
\hline$J_{25}=\min \left(26.97+25.76 N_{\mathrm{a}} ; 105.46-59.78 P_{\mathrm{a}}\right)$ & $\mathbf{0 . 3 0}$ & 1374.66 & 1390.91 & $<0.001$ \\
\hline \multicolumn{5}{|l|}{ Savanna (deciduous) } \\
\hline$J_{25}=45.60+14.01 N_{\mathrm{a}}$ & 0.23 & 861.59 & 869.44 & $<0.001$ \\
\hline$J_{25}=46.59+170.38 P_{\mathrm{a}}$ & 0.18 & 868.26 & 876.11 & $<0.001$ \\
\hline$J_{25}=40.56+10.27 N_{\mathrm{a}}+83.73 P_{\mathrm{a}}$ & 0.25 & 859.78 & 870.24 & $<0.001$ \\
\hline$J_{25}=21.18+21.91 N_{\mathrm{a}}+178.51 P_{\mathrm{a}}-53.96 N_{\mathrm{a}} P_{\mathrm{a}}$ & 0.26 & 859.05 & 872.12 & $<0.001$ \\
\hline$J_{25}=\min \left(51.28+13.06 N_{\mathrm{a}} ; 29.55+337.17 P_{\mathrm{a}}\right)$ & 0.29 & 855.17 & 869.25 & $<0.001$ \\
\hline \multicolumn{5}{|l|}{ Forest and savanna (deciduous and evergreen) } \\
\hline$J_{25}=38.23+19.42 N_{\mathrm{a}}$ & 0.30 & 2431.46 & 2442.36 & $<0.001$ \\
\hline$J_{25}=68.53+68.45 P_{\mathrm{a}}$ & 0.02 & 2528.29 & 2539.19 & 0.017 \\
\hline$J_{25}=40.06+20.09 N_{\mathrm{a}}-26.70 P_{\mathrm{a}}$ & 0.30 & 2432.37 & 2446.90 & $<0.001$ \\
\hline$J_{25}=15.87+32.06 N_{\mathrm{a}}+149.52 P_{\mathrm{a}}-83.38 N_{\mathrm{a}} P_{\mathrm{a}}$ & 0.33 & 2421.91 & 2440.09 & $<0.001$ \\
\hline$J_{25}=\min \left(29.42+24.36 N_{\mathrm{a}} ; 97.57+6.46 P_{\mathrm{a}}\right)$ & 0.33 & 2422.10 & 2441.28 & $<0.001$ \\
\hline
\end{tabular}

$N_{\mathrm{a}}$ nitrogen per unit leaf area $\left(\mathrm{g} \mathrm{m}^{-2}\right), P_{\mathrm{a}}$ phosphorus per unit leaf area $\left(\mathrm{g} \mathrm{m}^{-2}\right)$

Models addressed in detail in the "Results" and "Discussion" sections are highlighted in bold

shown for the forest species for the $P_{\mathrm{a}}$ relationships of Fig. 5b, d. In both cases, the bootstrapping analysis did, however, show the savanna co-limitation model $P_{\text {a }}$ slope to be significant with a 0.95 confidence interval for $V_{25}$ of 190-375 $\mu \mathrm{mol} \mathrm{CO} \mathrm{CO}_{2} \mathrm{~g}^{-1} \mathrm{P} \mathrm{s}^{-1}$ with the equivalent range being 246-539 $\mu \mathrm{mol} \mathrm{CO} \mathrm{g}^{-1} \mathrm{P} \mathrm{s}^{-1}$ for $J_{25}$ (Electronic Supplementary Material, Table S2).

Also shown for all four parts of Fig. 5 are fitted relationships from the original application of the dual-limitation model of (Domingues et al. 2010) to a wide range of West African tree species and location, including those with a much drier climate (grey lines). In all cases the 'West African' slopes are much steeper than found here for Cameroon, where the analysis has been confined to two forest-savanna transition zones. Differences at high $N_{\mathrm{a}}$ and $P_{\mathrm{a}}$ are particularly marked.

\section{Discussion}

Using as our individual unit of variation the individual leaf (rather than the tree or species), we found unequivocal support for our first hypothesis viz. that the scaling between foliar $\mathrm{N}$ and $\mathrm{P}$ and the nature of the photosynthesis-nutrient relationship would be different for forest and savanna species. This can be seen from Fig. $4 \mathrm{~d}$ where at any given leaf $\mathrm{N}$ (area basis) savanna trees had significantly higher $\mathrm{P}$ than their forest counterparts and Fig. 5 where the equations of Tables 2 and 3 clearly shown different relationships of both $V_{\mathrm{c}(\max )}$ and $J_{\max }$ with both $\mathrm{N}$ and $\mathrm{P}$ for forest vs. savanna species.

On the other hand, although we had also hypothesized that savanna trees should show more indications of being limited by $\mathrm{N}$, if anything the opposite was the case. This 
Fig. 5 Area-based relationships between a estimated Rubisco activity standardized to $25^{\circ} \mathrm{C}$ $\left(V_{25}\right)$ and leaf $\mathrm{N}, \mathbf{b} V_{25}$ and leaf $\mathrm{P}, \mathbf{c}$ estimated electron transport capacity at $25^{\circ} \mathrm{C}\left(J_{25}\right)$ and leaf $\mathrm{N}, \mathbf{d} J_{25}$ and leaf P. Deciduous forest (squares), evergreen forest (circles), savanna (triangles). Filled savanna symbols show points modelled to be limited by $\mathrm{P}$ as per the model fit of Eq. 1 as detailed in Electronic Supplementary Material, Table 1. Also shown from this study are the model fits of Eq. 1 for forest (full lines) and savanna (dotted lines), along with a previous fit of the same model to a mixture of forest and savanna species sampled along a precipitation transect in West Africa (grey lines) as detailed in Domingues et al. (2010)
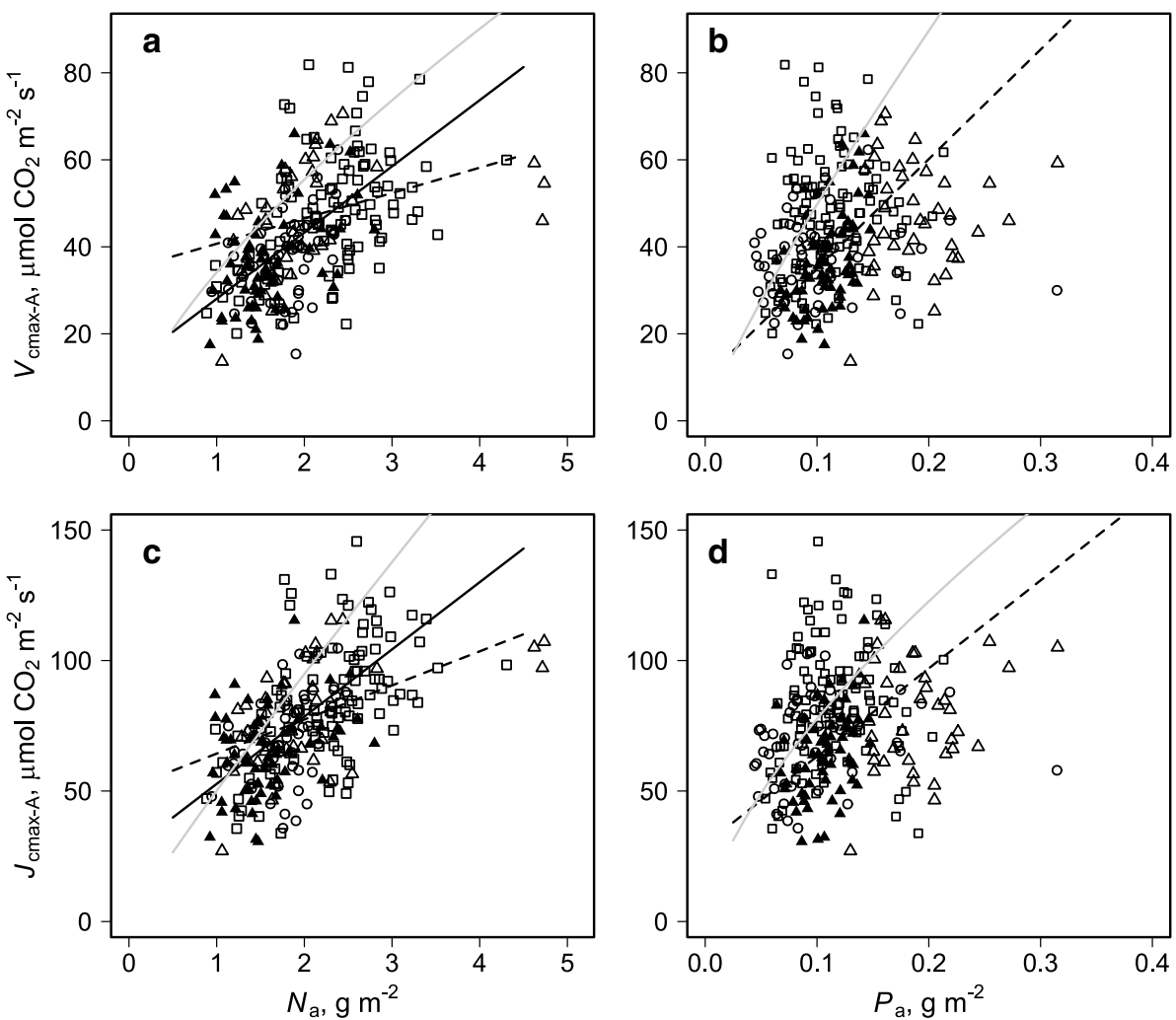

is because the best-fitting relationship between the photosynthetic parameters $V_{\mathrm{c}(\max )}$ and $J_{\max }$ for both evergreen and deciduous forest trees were a simple linear relationship with $N_{\mathrm{a}}$ with no relationship at all when a linear model with P content was tested. By contrast, the savanna species (all of which were deciduous) showed significant relationships with $P_{\mathrm{a}}$ as well as with $N_{\mathrm{a}}$-albeit with a different $\mathrm{N}$ dependence to that found for the forest species. Thus, if anything, the indications were for a greater limitation by $\mathrm{P}$ on photosynthesis in savanna as opposed to forest trees.

Biome history may be important in explaining these results. For example any forest refugia in Africa at the Last Glacial Maximum (Anhuf et al. 2006) would have been most likely to have occurred where both precipitation regime and soil conditions remained most favourable for forest tree function. So, with deeper tropical soils of a high water holding capacity also typically being of a low $\mathrm{P}$ status due to their long history of extreme weathering (Quesada et al. 2010), specific adaptions to a chronically low $P_{\mathrm{a}}$ for forest trees seem likely, for example in the replacement of phospholipids by galactolipids and sulpholipids under condition of low P supply (Lambers et al. 2012; Tjellström et al. 2008; Zhang et al. 2014).

With leaves intercepting light on a per unit area basis and spurious correlations possible when two unrelated area-based entities are transformed to a mass basis-the so called 'lulu effect' (Lloyd et al. 2013)-we saw for the current paper no practical reason to analyse our photosynthesis-nutrient dependencies on per unit mass basis (see also Osnas et al. 2013). Nevertheless, for the purposes of illustration our area-based analysis is repeated on a mass basis as part of the Electronic Supplementary Material (Tables S3, S4). This shows-in addition to the inevitable higher correlations associated with a 'common-element' correlation (Lloyd et al. 2013) — that for the forest species it is more often than not the more complex models involving not only both $N_{\mathrm{m}}$ and $P_{\mathrm{m}}$, but also their interaction, that have the lowest AIC and/or BIC. This is as opposed to the simple forest species linear $\mathrm{N}$ dependency for both $V_{25}$ and $J_{25}$ for the area-based fits. Overall these results are consistent with the assertion that in multivariate cases a simple area-to-mass conversion can easily give rise to variables not actually associated with the dependent variable appearing to be functionally linked (Lloyd et al. 2013). We also note that whilst the area-based models showed little bias in their residuals when examined as a function of $M_{\mathrm{a}}, N: P$ and a range of area based leaf-nutrient measures (Figs S3, S4), this was not the case for the mass-based models for which there was a bias towards positive residuals at low $M_{\mathrm{a}}$ (Figs S5, S6). The lack of any obvious dependency of the modelfit residuals on leaf cation concentrations, area-based leaf $\mathrm{S}$ or leaf $N: P$ ratios suggests that - at least in our case—-there is no need to invoke additional factors such as variations in leaf K (Battie-Laclau et al. 2014) into our dual-dependency 
N-P based model. Though that is not to say, of course, that such elements might not have important roles in influencing tropical vegetation structure and function independent of the photosynthetic process (Schrodt et al. 2014; Veenendaal et al. 2014).

With our earlier analyses using the formulation of Eq. 1 having actually focussed on mass-based model fits (Domingues et al. 2010), there does, however, remain the question: to what extent are some previous conclusions of Domingues et al. (2010) regarding the relative roles on $\mathrm{N}$ and P still valid? The answer is that, with only minor modifications, they still hold. For example, in that paper we also showed that area-based fits of the dual-limitation model implied a role for both $\mathrm{N}$ and $\mathrm{P}$ as alternate limiting factors for photosynthesis (in addition to the mass-based models) and with area-based comparisons with simple linear models also showing the min-min model to have the lowest AIC. Indeed, the analysis here should be best considered a refinement of the work of Domingues et al. (2010), probing further into the nature of the apparent different nutrient/ photosynthesis relationships identified for species associated with the different rainfall environments first identified there.

It is unlikely that the differences between forest and savanna in their photosynthesis-N relations (Figs. 4a, $5 \mathrm{a}, \mathrm{c})$ were simply a consequence of the sampled forest tree leaves being from a lower light environment. This is because considerable effort was put into ensuring that leaves from both vegetation formation types were sampled only from upper-canopy sun-exposed environments (See "Materials and methods"). Rather, and especially as broadly similar results have also been reported for a forest-savanna comparison in tropical northern Australia (Bloomfield et al. 2014), this difference between the two vegetation formation types in their photosynthesis-nutrient relationships seems something more fundamental. Both Domingues et al. (2010) and (Bloomfield et al. 2014) discuss at some length possible reasons for forest trees having an apparently less efficient use of $\mathrm{N}$, focussing on the idea of an increased allocation of $\mathrm{N}$ to non-photosynthetic compounds when conditions favouring a longer leaf longevity are also combined with a more variable light environment.

The question remains, however, as to the extent of the validity of the original parameterisation of Domingues et al. (2010), or the new forest parameterisation developed here, when applied to tropical forest trees growing on low-P availability soils, such as those which cover much of the eastern Amazon Basin (Quesada et al. 2011), especially as already investigated as part of the modelling studies of Mercado et al. (2011) and Fyllas et al. (2014). Trees on such soils do, nevertheless, typically have a foliage of a much lower $P_{\mathrm{a}}$ than encountered here (Table 2), so it will only be with further dedicated measurements under the full spectrum of $N: P$ variability and across a range of different growth forms that we will be able to ascertain the generality (or most likely otherwise) of any photosynthesis-nutrient relationships developed.

Most likely the dual-limitation model applies because for some specific locations and/or for some particular times of the year, $\mathrm{P}$ is rate limiting, whilst for other times/places it is $\mathrm{N}$ which constrains photosynthetic productivity. As for the Amazon Basin forest case discussed above, these regional variations, arising mostly from soil variationsbut also clearly depending on vegetation formation typewill give rise to variations in the rates of photosynthesis, these linking to variations in stand-level productivity (Fyllas et al. 2014; Mercado et al. 2011) and thus presumably important when parameterizing global vegetation models (e.g. Sitch et al. 2008 and Piao et al. 2013). This emphasizes a need for the development of new realistic models of ecosystem $\mathrm{N}$ and $\mathrm{P}$ cycling that include soil biogeochemical processes in a realistic manner (Fisher et al. 2010; Goll et al. 2012; Ostle et al. 2009; Thomas et al. 2013; Xu et al. 2012; Yang et al. 2013). But whatever the case, the results presented here along with those of other recent studies (Bloomfield et al. 2014; Domingues et al. 2010; Rossatto et al. 2013) clearly indicate that no single unifying woody tropical vegetation photosynthesis-nutrient relationship is likely to be found.

Author contribution statement TFD; collected and analyzed data, wrote manuscript, prepare figures, FYI; collected data, field support TF; collected data, field support, JG; institutional support, discussion of results, manuscript structure, GS; collected data, field support, OS; botanical identification, field support, FS; collected data, field support, BS; logistical support, botanical identification HT; botanical identification, field support, EV; discussion of results, manuscript structure SL; logistical support, site selection, field activities planning, JL; Project coordinator, manuscript writing, discussion of results.

Acknowledgments We gratefully acknowledge the many generous individuals who took part in the making of this work either in the field or in the UK. Fieldwork assistance was provided by A. den Holander and W. Zakaria and we also thank WCS-Cameroon and J. Sonké for logistical support. This work was funded through a UK Natural Environment Research Council TROBIT consortium award (references NE/D005590/1 and NE/D01185x/1) with additional support for Simon Lewis through a Royal Society University Research Fellowship. Shiela Lloyd assisted with manuscript preparation.

Open Access This article is distributed under the terms of the Creative Commons Attribution License which permits any use, distribution, and reproduction in any medium, provided the original author(s) and the source are credited. 


\section{References}

Anhuf D et al (2006) Paleo-environmental change in Amazonian and African rainforest during the LGM. Palaeogeogr Palaeoclimatol Palaeoecol 239:510-527

Battie-Laclau P et al (2014) Photosynthetic and anatomical responses of Eucalyptus grandis leaves to potassium and sodium supply in a field experiment. Plant Cell Environ 37:70-81. doi:10.1111/ pce. 12131

Bernacchi C, Singsaas E, Pimentel C, Portis A Jr, Long S (2001) Improved temperature response functions for models of Rubiscolimited photosynthesis. Plant Cell Environ 24:253-259

Bloomfield KJ et al (2014) Contrasting photosynthetic characteristics of forest vs. savanna species (Far North Qld, Australia). Biogeosci Discuss 11:8969-9011

Cernusak LA et al (2011) Responses of legume versus nonlegume tropical tree seedlings to elevated $\mathrm{CO}_{2}$ concentration. Plant Physiol 157:372-385

Chernick MR, LaBudde RA (2011) An introduction to bootstrap methods with applications to R. Wiley

Development Core Team R (2011) R: a language and environment for statistical computing. R Foundation for Statistical Computing, Vienna

Domingues TF et al (2010) Co-limitation of photosynthetic capacity by nitrogen and phosphorus in West Africa woodlands. Plant Cell Environ 33:959-980. doi:10.1111/j.1365-3040.2010.02119.x

Evans JR (1989) Photosynthesis and nitrogen relationships in leaves of $\mathrm{C}_{3}$ plants. Oecologia 78:9-19. doi:10.1007/BF00377192

Field CB, Mooney HA (1986) The photosynthesis-nitrogen relationship in wild plants. In: Givnish TJ (ed) The economy of plant form and function. Cambridge University Press, Cambridge, pp $25-55$

Fisher JB, Sitch S, Malhi Y, Fisher RA, Huntingford C, Tan SY (2010) Carbon cost of plant nitrogen acquisition: a mechanistic, globally applicable model of plant nitrogen uptake, retranslocation, and fixation. Global Biogeochem Cycles. doi:10.1029/200 9GB003621

Fyllas NM, et al (2009) Basin-wide variations in foliar properties of Amazonian forest: phylogeny, soils and climate. Biogeosciences 6:2677-2708. doi:10.5194/bg-6-2677-2009

Fyllas NM, Quesada CA, Lloyd J (2012) Deriving plant functional types for Amazonian forests for use in vegetation dynamics models. Perspect Plant Ecol Evol Syst 14:97-110. doi:10.1016/j. ppees.2011.11.001

Fyllas NM et al (2014) Analysing Amazonian forest productivity using a new individual and trait-based model (TFS v. 1). Geosci Model Dev 7:1251-1269. doi:10.5194/gmdd-7-1413-2014

Goll D et al (2012) Nutrient limitation reduces land carbon uptake in simulations with a model of combined carbon, nitrogen and phosphorus cycling. Biogeosciences 9:3547-3569

Gotsch SG, Geiger EL, Franco AC, Goldstein G, Meinzer FC, Hoffmann WA (2010) Allocation to leaf area and sapwood area affects water relations of co-occurring savanna and forest trees. Oecologia 163:291-301. doi:10.1007/s00442-009-1543-2

Hijmans RJ, Cameron SE, Parra JL, Jones PG, Jarvis A (2005) Very high resolution interpolated climate surfaces for global land areas. Int J Climatol 25:1965-1978. doi:10.1002/joc.1276

Hoffmann WA, Franco AC, Moreira MZ, Haridasan M (2005) Specific leaf area explains differences in leaf traits between congeneric savanna and forest trees. Funct Ecol 19:932-940

Hoffmann WA et al (2009) Tree topkill, not mortality, governs the dynamics of savanna-forest boundaries under frequent fire in central Brazil. Ecology 90:1326-1337. doi:10.1890/08-0741.1

Lambers $\mathrm{H}$ et al (2012) Proteaceae from severely phosphorus-impoverished soils extensively replace phospholipids with galactolipids and sulfolipids during leaf development to achieve a high photosynthetic phosphorus-use-efficiency. New Phytol 196:1098-1108

Lloyd J, Kriedemann PE, Aspinall D (1989) Comparative sensitivity of 'Prior Lisbon' lemon and 'Valencia' orange trees to foliar sodium and chloride concentrations. Plant Cell Environ 12:529540. doi:10.1111/j.1365-3040.1989.tb02126.x

Lloyd J, Goulden M, Ometto JP, Fyllas NM, Quesada CA, Patino S (2009) Ecophysiology of forest and savanna vegetation. In: Keller M, Gash J, Silva Dias P (eds) Amazonia and climate change. American Geophysical Union, Washington, DC, pp 463-484

Lloyd J, Bloomfield K, Domingues TF, Farquhar GD (2013) Photosynthetically relevant foliar traits correlating better on a mass vs. an area basis: of ecophysiological relevance or just a case of mathematical imperatives and statistical quicksand? New Phytol 199:311-321

Maisels F (2004) Cameroun: Mbam Djerem, vol. 27. Canopée, pp 2-6

Mayaux P, Bartholomé E, Fritz S, Belward A (2004) A new landcover map of Africa for the year 2000. J Biogeogr 31:861-877

Mercado LM et al (2011) Variations in Amazon forest productivity correlated with foliar nutrients and modelled rates of photosynthetic carbon supply. Philos Trans R Soc B Biol Sci 366:33163329. doi:10.1098/rstb.2011.0045

Mitchard E, Saatchi S, Gerard F, Lewis S, Meir P (2009) Measuring woody encroachment along a forest-savanna boundary in Central Africa. Earth Interact 13:1-29

Mitchard E et al (2011) Measuring biomass changes due to woody encroachment and deforestation/degradation in a forest-savanna boundary region of central Africa using multi-temporal L-band radar backscatter. Remote Sens Environ 115:2861-2873

Niinemets Ü (1999) Research review. Components of leaf dry mass per area - thickness and density — alter leaf photosynthetic capacity in reverse directions in woody plants. New Phytol 144:35-47. doi:10.1046/j.1469-8137.1999.00466.x

Osnas JL, Lichstein JW, Reich PB, Pacala SW (2013) Global leaf trait relationships: mass, area, and the leaf economics spectrum. Science 340:741-744

Ostle NJ et al (2009) Integrating plant-soil interactions into global carbon cycle models. J Ecol 97:851-863. doi:10.1111/j.1365-2745.2009.01547.x

Piao S et al (2013) Evaluation of terrestrial carbon cycle models for their response to climate variability and to $\mathrm{CO}_{2}$ trends. Glob Change Biol 19:2117-2132

Quesada CA et al (2010) Variations in chemical and physical properties of Amazon forest soils in relation to their genesis. Biogeosciences 7:1515-1541. doi:10.5194/bg-7-1515-2010

Quesada CA, Lloyd J, Anderson LO, Fyllas NM, Schwarz M, Czimczik CI (2011) Soils of Amazonia with particular reference to the RAINFOR sites. Biogeosciences 8:1415-1440. doi:10.5194/ bg-8-1415-2011

Quesada CA et al (2012) Basin-wide variations in Amazon forest structure and function are mediated by both soils and climate. Biogeosciences 9:2203-2246. doi:10.5194/bg-9-2203-2012

Ratnam J et al (2011) When is a 'forest' a savanna, and why does it matter? Global Ecol Biogeogr 20:653-660

Reich PB, Oleksyn J (2004) Global patterns of plant leaf N and P in relation to temperature and latitude. Proc Natl Acad Sci (USA) 101:11001-11006. doi:10.1073/pnas.0403588101

Reich PB, Oleksyn J, Wright IJ (2009) Leaf phosphorus influences the photosynthesis-nitrogen relation: a cross-biome analysis of 314 species. Oecologia 160:207-212

Rossatto D, Hoffmann W, de Carvalho Ramos Silva L, Haridasan M, Sternberg LL, Franco A (2013) Seasonal variation in leaf traits between congeneric savanna and forest trees in Central Brazil: implications for forest expansion into savanna. Trees 27:11391150. doi:10.1007/s00468-013-0864-2 
Schrodt F, Domingues TF, Feldpausch TR, Saiz G, Quesada CA, Schwarz M, Ishida FY, Compaore H,Diallo A, Djagbletey G, Hien F, Sonké B, Toedoumg H, Zapfack L, Hiernaux P, Mougin E, Bird MI, Grace J,Lewis SL, Veenendaal EM, Lloyd J (2014) Foliar trait contrasts between African forest and savanna trees: genetic versus environmental effects. Funct Plant Biol 42:63-83. doi:10.1071/FP14040

Sitch S et al (2008) Evaluation of the terrestrial carbon cycle, future plant geography and climate-carbon cycle feedbacks using five dynamic global vegetation models (DGVMs). Glob Change Biol 14:2015-2039

Thomas RQ, Zaehle S, Templer PH, Goodale CL (2013) Global patterns of nitrogen limitation: confronting two global biogeochemical models with observations. Glob Change Biol 19:2986-2998

Tjellström H, Andersson MX, Larsson KE, Sandelius AS (2008) Membrane phospholipids as a phosphate reserve: the dynamic nature of phospholipid-to-digalactosyl diacylglycerol exchange in higher plants. Plant Cell Environ 31:1388-1398

Torello-Raventos M et al (2013) On the delineation of tropical vegetation types with an emphasis on forest/savanna transitions. Plant Ecol Divers 6:101-137. doi:10.1080/17550874.2012.762812

Veenendaal EM et al (2014) Structural, physiognomic and aboveground biomass variation in savanna-forest transition zones on three continents. How different are co-occurring savanna and forest formations? Biogeosci Discuss 11:4591-4636

Von Caemmerer S (2000) Biochemical models of leaf photosynthesis. CSIRO, Melbourne

Walter H, Mueller-Dombois D (1971) Ecology of tropical and subtropical vegetation. Oliver and Boyd, Edinburgh

Warton DI, Wright IJ, Falster DS, Westoby M (2006) Bivariate linefitting methods for allometry. Biol Rev 81:259-291

White F (1983) The vegetation of Africa, a descriptive memoir to accompany the UNESCO/AETFAT/UNSO vegetation map of Africa (3 Plates, Northwestern Africa, Northeastern Africa, and Southern Africa, 1:5,000,000). United Nations Educational, Scientific and Cultural Organization, Paris

Xu C, Fisher R, Wullschleger SD, Wilson CJ, Cai M, McDowell NG (2012) Toward a mechanistic modeling of nitrogen limitation on vegetation dynamics. PLoS One 7:e37914

Yang X, Post WM, Thornton PE, Jain A (2013) The distribution of soil $\mathrm{P}$ for global biogeochemical modeling. Biogeosciences 10:2525-2537

Zhang Z, Liao H, Lucas WJ (2014) Molecular mechanisms underlying phosphate sensing, signaling, and adaptation in plants. $\mathrm{J}$ Integr Plant Biol 56:192-220. doi:10.1111/jipb.12163 